\title{
4
}

\section{Gender equality and a rights- based approach to tax reform}

\author{
Helen Hodgson and Kerrie Sadiq
}

This chapter applies a human rights framework to gender inequality in tax policy. Gender inequality in economic reform is a global issue. In its recent report, Progress of the World's Women (the UN Report), UN (United Nations) Women applies international human rights standards to assess laws and policies for substantive gender equality (UN Women 2015). The UN Report confirms that women's rights cannot and should not be separated from general principles of social and economic justice, and macro-economic and fiscal policy should not be designed in isolation from a human rights agenda; on the contrary, human rights should be one of the drivers of economic reform (UN Women 2015, p. 26).

UN Women is the UN entity responsible for promoting women's empowerment and gender equality. In the UN Report, UN Women advocates for a rights-based macro-economic agenda that will ensure that human rights, including the right to education and dignified employment, are protected, and are driving the process of macro-economic reform. In this chapter, we use this report as the starting point for demonstrating why a human rights framework should be used in the design of tax policy specifically. Our approach can be contrasted with approaches that focus more directly on redistributive measures. For instance, the International 
Monetary Fund (IMF), in its recent report on fiscal policy and income inequality (IMF 2014), places a greater emphasis on targeting transfers rather than our broad-based, encompassing approach to tax policy.

We propose in this chapter the use of a framework for fiscal policy that incorporates human rights principles that address gender inequality. That is, human rights obligations need to be built into fiscal policy. In the next part, we discuss the relevant human rights treaties and set out and adopt the UN Women (2015) framework. We then apply this UN Women framework to the Australian tax system as a case study. We examine four common taxes (personal income tax (PIT), goods and services tax (GST), property taxes and taxes on retirement savings) to determine the extent of any inherent tax bias, then apply a human rights gendered lens to examine a range of tax reform proposals. In particular, we consider the impact that any reforms may have on the economic and social rights of women.

\section{A rights-based approach}

This chapter takes a human rights approach to gender inequality in tax systems, following Elson (2006) in this approach to budgets. The human rights implications of tax-transfer policy is a common thread throughout this book; see, for example, Kathleen Lahey's discussion of taxing for gender equality in Chapter 2 and Patricia Apps' discussion about the effects of gender discrimination in PIT policy in Chapter 3. Other authors have previously adopted an equality approach (Stotsky 1997) or a capabilities approach (Stewart 2011). Even in gender analysis, human rights obligations have not usually been embedded into fiscal policy, which is generally analysed separately for any gender impact on the basis of equity principles.

\section{Gender impact analysis}

Susan Himmelweit (2002, p. 50) argues that a gender impact analysis of fiscal policy allows an assessment of both the direct and indirect impact of budgetary proposals in deciding whether reforms should proceed. However, while this impact assessment can be applied at every stage of policy making, it is not fully incorporated into policy design. That is, such an analysis is separate and evaluative rather than embedded in the process of reform. In Himmelweit's approach (2002, pp. 64-65), a gender impact analysis of economic policy applies three principles. First, policies 
are assessed on both paid and unpaid economies. Second, there is an assessment of the distribution between men and women. Third, equity is evaluated both between and within households. Each of these assessments is valuable, but they provide a framework for assessing evidence of gender inequality and offer accountability solutions, rather than providing a framework for alleviating gender inequality within a macro-economic policy framework.

\section{Equality in substance}

As UN Women reminds us (UN Women 2015), equality in the law between men and women does not guarantee equality in practice. Formal equality is a separate concept from substantive equality or genuine fiscal equality. While equal rights embedded in the legal system provide a central reference point and reflect policy shifts, 'entrenched inequalities, discriminatory social norms, harmful customary practices, as well as dominant patterns of economic development can undermine their implementation and positive impact' (UN Women 2015, p. 12). Rather than the adoption of laws that treat men and women equally, substantive equality considers the application of these laws and the subsequent results and outcomes. As UN Women explains further:

The concept of substantive equality arose out of the recognition that because of the legacy of historical inequalities, structural disadvantages, biological differences and biases in how laws and policies are implemented in practice, formal equality is not enough to ensure that women are able to enjoy the same rights as men. To achieve substantive equality, therefore, requires both direct and indirect discrimination to be addressed. It also requires specific measures to be adopted that redress women's disadvantages and, in the longer term, the transformation of the institutions and structures that reinforce and reproduce unequal power relations between women and men (UN Women 2015, p. 35).

Stotsky (1996) was among the first to recognise substantive difference in a global context and her framework of explicit and implicit bias is seen as a foundational tool for analysis. Explicit biases arise where the law specifically establishes rules that treat men and women differently. Implicit biases are more pervasive, and arise where the operation of the rules has a different effect on men and women, based on the interaction of the tax laws with social and economic norms. Consequently, explicit 
biases may be observed and addressed through formal equality measures, while implicit biases may be observed and addressed with substantive equality measures.

Subsequent research includes Barnett and Grown's (2004) hypothetical tax typology to develop recommendations for developed and emerging economies based on their level of development and the range of tax bases available. Also of significance is Grown and Valodia's (2010) comparative gender analysis across 10 countries with different levels of economic development and different tax systems.

While offering insight into explicit and implicit gender inequality issues, the above frameworks have been criticised as being based on the criteria of equal treatment for men and women (Elson 2006, p. 77; Young 1999). As such, they arguably fail to recognise and address differences between women and men, as required under various human rights treaties explained below. Hence, the identification of explicit or implicit bias is only the starting point. Explicit bias can be addressed through adopting an equality framework, but implicit bias needs more nuanced policy, and is best addressed through a human rights or capabilities framework.

Equality needs to be considered in the context of not only opportunities but also outcomes. Consequently, different treatment may be required to achieve substantive equality. The need for such an approach is well understood in a human rights context but is little understood in an economic policy context. UN Women explains:

the concept of substantive equality has been advanced in key human rights treaties to capture this broader understanding: that inequality can be structural and discrimination indirect; that equality has to be understood in relation to outcomes as well as opportunities; and that 'different treatment' might be required to achieve equality in practice (UN Women 2015, p. 35).

A human rights approach allows policymakers to adopt differential treatment where it is necessary to address discrimination in macroeconomic policy. 


\section{Fiscal equality}

Kathleen Lahey argues that women's fiscal equality is fundamental to all human rights (see, for example, Chapter 2, this volume; and Lahey 2015, p. 10). Logically, macro-economic policy and its subset of fiscal policy should take into account the human rights principles to which governments have committed. UN Women proposes that action is required in three interrelated areas: redressing women's socio-economic disadvantage; addressing stereotyping, stigma and violence; and strengthening women's agency, voice and participation. Part of the progress towards substantive equality relates to women's rights to information about laws, government policy and budgetary details, including the right to scrutinise public budgets to 'ensure public services meet women's needs better; and having access to a range of high quality services can in turn support women's right to work, creating powerful synergies' (UN Women 2015, p. 13).

UN Women stresses that if substantive equality is to be achieved, economic and social policies must work in tandem, although traditionally economic policy is seen as promoting economic growth while social policy addresses its 'causalities', such as poverty and inequality. Economic policy can pursue the goal of gender equality and social justice, while social policies can contribute to economic growth. UN Women states:

The specific policy package to achieve substantive equality will differ from context to context. Ultimately, the aim is to create a virtuous cycle through the generation of decent work, gender-responsive social protection and social services, alongside enabling macroeconomic policies that prioritize investment in human beings and the fulfilment of social objectives (UN Women 2015, p. 13).

While UN Women provides for targeted 'grass roots' action, it also recognises that broad-based priority areas within a policy-based framework must be prioritised. In addition to decent work for women and gender-responsive social policies, UN Women views rights-based macro-economic policies as a key priority area.

\section{Applying human rights treaties}

Human rights treaties have been signed by many nations, with two especially significant in the global context and specifically relevant in the Australian fiscal policy context: the International Covenant on Economic, Social and Cultural Rights (ICESCR) and the Convention on the 
Elimination of All Forms of Discrimination Against Women (CEDAW). These treaties are recognised as important contributors to macro-economic policy, not only to guide that policy but especially in the context of the need for temporary special measures to correct for indirect discrimination. This is particularly relevant where there is a lack of substantive equality and applies where gender-neutral policies are actually modelled on male norm and lifestyles, and inherently incorporate stereotypical expectations, attitudes and behaviour (UN Women 2015, p. 36).

The ICESCR (1966) was ratified by Australia on 10 December 1975. In its Preamble, it recognises that:

in accordance with the Universal Declaration of Human Rights, the ideal of free human beings enjoying freedom from fear and want can only be achieved if conditions are created whereby everyone may enjoy his economic, social and cultural rights, as well as his civil and political rights (ICESCR 1966, Preamble).

These socio-economic rights are understood to include the right to education, housing, health care and a certain standard of living. As part of those rights, there is a broad obligation of signatories to ensure the equal right of men and women to the enjoyment of all economic, social and cultural rights set forth in the present Covenant (ICESCR Article 3). Other significant Articles, discussed below, include the right to work (ICESCR Article 6), social security (ICESCR Article 9), protection and assistance to the family (ICESCR Article 10) and an adequate standard of living (ICESCR Article 11).

The treaty CEDAW (1979) was ratified by Australia on 28 July 1983. The CEDAW is generally understood to be a 'bill of rights' for women and contains 30 Articles defining key principles of equality 'based on the belief that basic human rights include the true equality of men and women' (HRC 2015). As a signatory, Australia has committed itself to ensuring the elimination of discrimination against women, defined in Article 1 as:

any distinction, exclusion or restriction made on the basis of sex which has the effect or purpose of impairing or nullifying the recognition, enjoyment or exercise by women, irrespective of their marital status, on a basis of equality of men and women, of human rights and fundamental freedoms in the political, economic, social, cultural, civil or any other field (CEDAW 1979, Article 1). 
Previous studies have adopted a CEDAW perspective as the basis for analysing public revenue, also drawing on the work of gender budgeting initiatives (e.g. Elson 2006). The uses and implications of gender budgeting are discussed further in Chapters 2, 10 and 11 of this book. These studies provide useful insights into current tax regimes. However, again, these studies tend to evaluate existing taxes rather than provide the foundation for reform with human rights obligations built into the fiscal policy framework. That is, rather than starting from a human rights perspective, these studies recognise the current criteria of tax reform design (efficiency, equity and ease of administration) as the design principles and reconceptualise current policy though a human rights lens. As an alternative, we propose that human rights obligations need to be built into fiscal policy.

The two treaties, when incorporated into fiscal policy, must work in tandem to achieve substantive gender equality. While the CEDAW provides an understanding of what is meant by gender equality and is specifically targeted at discrimination against women, the ICESCR addresses women's economic and social rights. These treaties set the obligations of signatory states and provide the basis for legislative change as well as obligations and guidance on appropriate means of addressing inequality. They require states to take a proactive role in ensuring equality in social and economic rights.

Once entrenched in domestic legislation:

[these] laws that establish that women and men have equal rights provide the basis for demanding and achieving equality in practice. They are a touchstone for political and cultural struggles, set standards and incentives for changes in social norms and attitudes and influence shifts in policy (UN Women 2015, p. 28).

However, there are recognised limitations as legislative changes are only part of the story with such obligations providing 'the ethical basis and inspiration for collective action to change policies as well as social norms, attitudes and practices' (UN Women 2015, p. 16). As UN Women explains:

human rights principles are also an important basis for the design of policies, for monitoring their implementation and outcomes and for holding all duty-bearers-States as well as global institutions and corporations-to account for the realization of substantive equality (UN Women 2015, p. 17). 
Human rights principles and the ensuing legislative enactment of the required standards provide the basis for equality with 'power inequalities, structural constraints and discriminatory social norms and practices' needing to be addressed (UN Women 2015, p. 24). Despite the implementation of these treaties, women continue to experience economic inequality and it is suggested, therefore, that states 'have a proactive role as arbiters of social and economic rights' (UN Women 2015, p. 25) and human rights commitments must be incorporated into macro-economic policy if there is to be substantive gender equality.

\section{Rights-based fiscal policies}

To be effective, a global approach to human rights needs to be incorporated into state-based policies to support gender equality. The economic environment of a nation is created through its macro-economic policies, which, in turn, 'shape the overall economic environment for realising women's economic and social rights' (UN Women 2015, p. 194). Traditional macro-economic policy focuses on fiscal (tax and government expenditure) and monetary policy for the creation of jobs, wealth and improved living standards (Dolamore 2015). This policy has a significant effect on paid employment and fiscal resources needed to implement social policies and programs. Because of the emphasis on paid employment, macro-economic policies fail to adequately consider the importance of unpaid care and domestic work as well as non-market investments in people (UN Women 2015, p. 192) (see also the discussion by Julie Smith in Chapter 6).

Macro-economic policies provide the foundation for advancing substantive equality for women because they affect gender equality in four distinct ways: a direct impact on the quantity and quality of employment opportunities; the burden of unpaid care and domestic work; distributive consequences through taxation; and resources available to finance social policies (UN Women 2015, pp. 194-196). Macro-economic policy is traditionally regarded as gender-neutral. As such, it customarily fails to take into account substantive gender equality, instead focusing on the operation of the economy as a whole to provide a stable economic environment, which, in turn, fosters strong and sustainable economic growth. Kathleen Lahey explains that this has occurred because 'fiscal policies are constructed around one goal-taxing for growth-and largely ignore taxing for social needs' $(2015$, p. 8). However, distributive 
consequences are not gender-neutral. Nor are many gendered assumptions inherent in what appear to be gender-neutral tax regimes (Nelson 2015). This does not necessarily mean that taxing for growth and taxing for social policy are in opposition to each other. Rather, broad fiscal policy should include both, allowing the two to complement each other.

The current, narrowly focused, approaches to macro-economic policy, has an emphasis on growth of gross domestic product (GDP) that means structural disadvantages faced by women are not addressed (UN Women 2015, p. 196). GDP itself is measured according to goods and services produced, which means that non-market services (unpaid care and domestic work) are excluded, reinforcing the stereotype of the lack of value in such work. While the causal relationship between GDP growth and gender equality is mixed, within a human rights context, UN Women argues, first, that GDP growth is only successful if it leads to better social outcomes, which includes gender equality; second, that the lack of focus within macro-economic policy on employment creation limits the ability to address women's socio-economic advantage in the labour market; and third, that restrictive macro-economic policy choices affect the ability to fund gender equality social policy initiatives and ensure that the tax system has positive redistributive consequences (UN Women 2015, p. 19.).

These issues are seldom addressed through macro-economic policies. This is despite the recognition that:

markets do not always function well; unregulated markets can result in financial crises, too little employment, an inadequate supply of public goods and services and environmental deterioration; distribution matters; and inequality affects economic stability and performance (UN Women 2015, p. 210).

In contrast, feminist macro-economists have developed frameworks that incorporate broader concepts such as unpaid labour and consider distributive outcomes. Building on this, a human rights-based approach to macroeconomic policy requires a broader set of objectives to be considered, as well as the inclusion of social policies such as gender equality (UN Women 2015, p. 15). Such an approach can lead to, among other things, the democratisation of economic governance (UN Women 2015, p. 193).

UN Women suggests that the key principles and obligations for a human rights-based macro-economic policy are non-discrimination and equality; minimum essential levels of social and economic rights; progressive 
realisation and preventing policy reversals; maximum available resources; accountability, transparency and participation; and extraterritorial obligations (UN Women 2015, pp. 210-211). The Centre for Economic and Social Rights, a not-for-profit international human rights organisation, also highlights what it believes are the crucial functions of tax from a human rights perspective: resourcing, redistribution, representation and re-pricing (Donald 2015). UN Women summarises the value of a robust fiscal regime in the human rights context as follows:

Human rights emphasize the dignity and freedom of the individual, but their realization depends heavily on solidarity and collective action. Putting in place policies for substantive equality requires collective financing, ideally through progressive taxation. The narrow targeting of social protection to the poorest households may seem to make it more affordable than building universal systems that benefit everyone. But universal systems can actually expand financing options by increasing the willingness of middle and higher income groups to pay taxes for wellfunctioning education, health or pension systems that they would also use (UN Women 2015, p. 17).

\section{The UN Women framework}

Within a fiscal policy context, there are numerous measures that can be adopted as part of the tax-transfer system. UN Women suggests four broad fiscal policy considerations (UN Women 2015, pp. 15-16) and associated tax strategies, which are adopted in this chapter. In Table 4.1, we suggest and adopt the UN Women framework for considering human rights obligations within fiscal policy.

Table 4.1: Fiscal policy strategies for a human rights framework

\begin{tabular}{|l|l|}
\hline Fiscal policy & Tax strategies \\
\hline $\begin{array}{l}\text { Raise resources for gender- } \\
\text { sensitive social protection } \\
\text { and social services by } \\
\text { enforcing existing tax } \\
\text { obligations. }\end{array}$ & $\begin{array}{l}\text { Improve the efficiency of tax collection through } \\
\text { addressing institutional and capacity constraints, which } \\
\text { can mobilise additional resources even if the tax mix } \\
\text { and tax rates do not change. }\end{array}$ \\
\hline $\begin{array}{l}\text { Reprioritise expenditure } \\
\text { (e.g. reducing expenditure } \\
\text { on defence and increasing } \\
\text { expenditure on social } \\
\text { services). }\end{array}$ & $\begin{array}{l}\text { Reprioritise expenditures towards areas that advance } \\
\text { gender equality and support the realisation of rights. } \\
\text { Design tax systems to redistribute income and to } \\
\text { redress socio-economic disadvantage by ensuring } \\
\text { that women and marginalised groups are not } \\
\text { disproportionately burdened. } \\
\text { Use gender-responsive budgeting to guide revenue } \\
\text { mobilisation and spending decisions. }\end{array}$ \\
\hline
\end{tabular}




\begin{tabular}{|l|l|}
\hline Fiscal policy & Tax strategies \\
\hline $\begin{array}{l}\text { Expand the overall tax base } \\
\text { (minimising or removing tax } \\
\text { exemptions and allowances } \\
\text { that primarily benefit } \\
\text { wealthier groups). }\end{array}$ & $\begin{array}{l}\text { Increase tax revenues by introducing new taxes and } \\
\text { tax policies that generate resources from under-taxed } \\
\text { areas, such as the financial sector or natural resource } \\
\text { exports. }\end{array}$ \\
\hline $\begin{array}{l}\text { Global policy coordination } \\
\text { to minimise spill-overs and } \\
\text { ensure governments can } \\
\text { mobilise resources. }\end{array}$ & $\begin{array}{l}\text { Global cooperation for the realisation of economic } \\
\text { and social rights could be achieved through the } \\
\text { universal acceptance of extraterritorial obligations of } \\
\text { governments with regard to the realisation of rights } \\
\text { beyond their own borders, as outlined in the Maastricht } \\
\text { Principles, which include consideration of the roles } \\
\text { of transnational corporations, non-governmental } \\
\text { organisations and intergovernmental institutions. }\end{array}$ \\
\hline
\end{tabular}

Source: Adapted from UN Women (2015, pp. 15-16).

The strategies in Table 4.1 encompass accountability measures, both domestically and globally, as well as measures that address the adequacy and distribution of tax revenue. The end goal of a human rights-based macro-economic policy that incorporates gender equality issues is the recognition of economic and social rights for all (UN Women 2015, p. 209). However, the balance between social and economic policy must also be considered. Even when the divisions between social and economic policy are removed and the two are seen as one, there should not be an overemphasis on economic growth to the detriment of social justice. As Kathleen Lahey points out, this has not been the traditional approach:

For more than a generation, the IMF and the World Bank have pushed governments to prioritise economic growth over social justice in their approach to fiscal policy. The results of this experiment are now in; sluggish growth, steepening inequality and the continued subjugation of women. It is time for a new vision of development, in which real needs take precedence over the fantastical desires that incubate in the global institutions (Lahey 2015, p. 8).

\section{A rights-based approach to tax reform}

There are numerous measures that a state can take to ensure that a rightsbased approach to fiscal policy is adopted. Most obviously, it is the general tax system that funds investment in public services. Ensuring that enough revenue is raised can be achieved by enforcing the current tax regime as well as expanding the tax base. However, in doing so, a state needs to be mindful of the distributive effects, along with the progressivity of taxes. 
States also need to be able to mobilise their resources without deterrence felt by the tax policies of other countries with preferential tax regimes. A global environment needs to be created to ensure that economic and social policies are seen as connected.

The effect of different taxes in the tax mix also needs to be considered within a human rights framework. The main issues to consider when human rights principles are applied to entire programs of tax reform are the balance between corporate and PIT, and the balance between direct and indirect tax (Elson 2006, p. 95). Previous analysis also suggests that when corporate taxes are lowered personal taxes are increased, and when income taxes are reduced sales taxes are increased, all with a greater incidence of tax falling on women (UN Women 2015, p. 76).

UN Women makes the case that progressive taxes are directly related to community solidarity (UN Women 2015, p. 207). It lists income tax as most progressive, followed by earmarked taxes, indirect taxes, public then private insurance schemes, user fees and self-provision as the most regressive forms of financing the provision of social services (UN Women 2015, p. 207). Barnett and Grown (2004) studied the effect that different tax bases have on the economic activities of women across a range of countries with different levels of development. The gender-tax typology developed in that study ranged from countries with a low level of economic development, where tax bias is more likely to be implicit, and the principal tax recommendations relate to targeted relief and exemptions; to countries where women's economic activities are fully integrated, and the primary recommendations are to remove explicit bias and to increase progressivity in the system through increased MTRs and targeted low-income relief.

Barnett and Grown (2004) make their first recommendation the removal of any explicit bias in the tax system. Any such bias would be clearly contrary to Article 2 of CEDAW, which requires that signatory states:

Eradicate discrimination against women by introducing new laws or policy, changing existing discriminatory laws and providing sanctions for discrimination where it occurs (CEDAW 1979, Article 2).

We argue that a human rights framework requires that the governments address inequality by directing more resources to removing barriers to full economic participation by women. Specifically, the PIT, GST, taxes on capital, property taxes and retirement savings taxes should all be considered within a fiscal policy setting that incorporates human rights 
obligations. While explicit discrimination can be addressed through legislative reform, implicit bias is systemic and more difficult to address. Economic gender gaps tend to arise from societal norms and expectations, particularly labour market stereotypes about suitable occupations, social norms that assume women will take primary responsibility for domestic chores and the care of young children and the power of social norms so that women don't exercise their rights. CEDAW Article 5 specifically requires signatories to:

Address and change social and cultural patterns that reinforce the stereotyping of women and traditional gender roles, or that promote the relative superiority or inferiority of either of the sexes (CEDAW 1979, Article 5).

In order to increase access to work, Article 10 of ICESCR requires signatories to provide protection to new mothers, including access to paid parental leave, and CEDAW requires signatories to address social and cultural patterns that reinforce gender stereotypical roles (Article 5), and ensure that women have the same training and employment opportunities as men (Article 10). This requires a greater fiscal investment in policies around paid parental leave and child care.

There is an increasing political awareness in Australia of the issues surrounding women's workforce participation as a means to improving the economic wellbeing of women (Senate Economics Reference Committee 2016). However, consistent with the austerity regimes adopted internationally, the Turnbull Government is seeking to fund any expansion of these programs to increase workforce participation through existing portfolio reallocations (e.g. proposing that funding for increased child care come from savings in existing programs). Notably, the UN Women framework classifies self-provision as the most regressive form of provision of social services, yet this is the norm for many women who are unable to access adequate or appropriate child or elder care. We argue that a human rights framework requires that the government direct more resources to removing barriers to full economic participation by women.

In the balance of this chapter, we examine four common taxes and social insurance systems against the human rights treaties ICESCR and CEDAW. This discussion draws on Australia as a case study of a developed nation that is a signatory to the treaties. 


\section{Personal income tax-transfer system}

\section{Progressivity of income tax}

Although PIT is the most progressive tax, there has been a clear trend across the Organisation for Economic Co-operation and Development (OECD) countries since the 1980s to flatten PIT rate schedules. Among emerging nations, income tax tends to be less significant as a source of revenue than among developed nations (World Bank 2015).

There is a global trend to reduce the effective tax rates on investment income in order to counter the mobility of capital. Literature also suggests that lower tax rates on savings encourages increased savings among low-income earners, although higher income earners are more likely to redirect savings into tax-preferred models (OECD 2007). However, there is evidence that a reduction in the corporate tax rate leads to a greater reliance on other taxes to meet the fiscal requirements of government. Elson (2006, p. 95) documents examples where the burden is shifted either to PIT or, more usually, to indirect taxes to ensure fiscal adequacy. If that shift were to make PIT more progressive it would provide additional revenue to provide social services, but, historically, PIT reform measures have led to flatter PIT schedules.

Women are over-represented among lower income earners and pay less PIT as a result. However, tax reform that reduces PIT rates is not only regressive but reduces revenue available to governments to deliver social services. This creates a feedback loop: governments cannot afford to provide care services, pushing the burden back to women who may further reduce their hours in the paid workforce in order to provide unpaid care.

Studies of the gender wealth gap (e.g. Austen et al. 2014; Cobb-Clark and Hildebrand 2011) also show that the composition of the assets held by single women includes a higher proportion of wealth held in the primary home than in other asset classes, while men are more likely to hold wealth portfolios with a larger proportion of financial assets. As such, proposals that reduce the tax on investments are likely to deliver higher benefits to male investors.

Tax on income from investments, including tax on the gain from realisation of capital assets, is strongly progressive if included in a global definition of income and taxed at general progressive rates. This is because 
high-income earners derive a higher proportion of their income from investments than low-income earners. Conversely, many countries impose a schedular tax system under which capital income is taxed at a flat rate, or a final withholding tax (Harding 2013). Such systems disadvantage low-income earners who pay PIT rates below the statutory withholding rate on their earned income, including investors and retirees who are supporting themselves from the returns on those investments.

A significant element of the tax reform debate in Australia is the proposal to lower the company tax rate in order to encourage foreign investment in Australian companies. Australian Treasury modelling (Treasury 2015, p. 78) suggests that the economic benefits of a company tax rate cut would be shared among shareholders, customers and employees. However, a lower company tax rate also causes tax planning. In the Australian context, the gap between the top MTR of the PIT and the corporate rate (currently 19 per cent) drives decisions regarding business structures and encourages tax minimisation (Treasury 2015, p. 80). The caveat on this argument is that the dividend imputation system washes out the benefit of the reduction in corporate tax in respect of Australian shareholders when dividends are received (rather than profits being retained).

In Australia, capital gains are included in assessable income when gains are realised, but a discount reduces the taxable gain by 50 per cent. A review of Australian Tax Office (ATO) data shows that although taxpayers across all income ranges derive capital gains, about 3 per cent of taxpayers with a taxable income below $\$ 80,000$ received capital gains, compared to 6.6 per cent of taxpayers with a total income between $\$ 100,000$ and $\$ 150,000$ and 19 per cent of taxpayers with a total income of more than $\$ 500,000$ (ATO 2012, Table 9). Consequently, reducing the tax rate on capital gains tax is regressive and also likely to reduce revenue collections.

We argue that reform of taxation on capital assets must expand the tax base by removing exemptions, and make additional revenue available to redirect toward areas of social spending. Consequently, reductions in corporate taxes and other investment taxes are not consistent with a human rights approach to tax reform. 


\section{The tax and transfer unit}

The relevant human rights treaties require that signatory states not only ensure equal economic rights to men and women (ICESCR Article 3; CEDAW Article 3) but specifically recognise the right to work (ICESCR Article 6; CEDAW Article 11). Barriers to workforce participation through joint tax systems and high effective marginal tax rates (EMTRs) are potentially in breach of these treaty obligations.

As discussed in several other chapters of this volume, the disincentive effects on women's work of a joint (couple) tax unit are well recognised in the economic literature. The secondary income earner in a household effectively bears a higher tax rate than the primary earner, reducing participation incentives on both efficiency and equity grounds.

Both treaties recognise the right of people to transfer payments:

ICESCR Article 9: Recognise the right of everyone to social security, including social insurance ... (ICESCR 1966, Article 9)

CEDAW Article 13: Women have equal access to family benefits, forms of financial credit, including mortgages, and the same rights as men to participate in recreational activities and cultural life ... (CEDAW 1979, Article 13)

The choice of the tax and/or transfer unit can also create a couple, or marriage, penalty or bonus where the joint tax payable differs from the tax payable by two individuals (see, for example, Adam and Brewer 2012, discussing the United Kingdom; Hodgson 2008).

The unit of assessment for the tax system may not be the same as for the transfer system. Under tax and benefit systems where the individual is the unit of assessment for tax purposes but the couple is the unit for transfer purposes, there is a mismatch that can result in the application of a couple penalty that may discourage participation in the labour market. When the tax unit operates in conjunction with a means-tested transfer system on a joint or household basis, the MTR compounds with the withdrawal of transfer payments, resulting in high EMTRs (Apps 2010).

Australia's personal income tax-transfer systems do not include any formal bias, with formal equality in tax-transfer legislation. Primary carers and spouses are recognised as gender-neutral, although the data reflect social norms, showing that primary carers are predominantly female and that 
male workforce participation rates are higher. Significantly, women still undertake more unpaid care than men, most while maintaining engagement with the paid economy, leading to one of the highest rates of part-time female workforce participation in the OECD (Craig 2007; Baird et al. 2017).

While Australia has adopted the individual as the tax unit, its transfer payments are determined on the basis of household income. Australia has paid payments in respect of dependants directly to the primary carer since the 1980s, apart from a short period in the late 1990s. However, as most family benefits are means tested on the basis of family income, a couple penalty arises when the primary carer assesses whether to increase paid work, as the EMTR on those earnings is considerably higher than the MTR if the primary earner takes on additional work (Apps 2010).

Although high EMTRs are recognised as a major deterrent to workforce participation rates, Australian measures to address the issue to date have been focused on the restructuring of transfer payments to withdraw eligibility for benefits from women when their children reach a certain age. This may have the desired effect of motivating women to increase their workforce participation. However, in the absence of other forms of support, it could merely reduce the income of that family, increasing disadvantage among single-income families, in contravention of ICESCR Article 11, which requires signatory states to ensure 'an adequate standard of living for himself and his family' (ICESCR 1966, Article 11).

\section{Broad-based consumption tax}

The second major tax base is a broad-based consumption tax, generally imposed as either a value added tax (VAT) or a GST, and levied in about 160 countries globally. Bias in consumption tax systems depends on the extent of any exemptions in the base on which the consumption tax is levied. Generally, the fewer exemptions in the consumption tax base, the less likelihood there is of explicit bias occurring in the system.

The ICESCR specifically recognises that states should protect the right to an adequate standard of living, including food, clothing, housing (Article 11) and health (Article 12). The CEDAW adds the protection of equal access to education and training (Article 10). Targeted exemptions and concessions in these areas would protect access to these basic rights. 
The earning and allocation of household income is still gendered (Baxter et al. 2008; Himmelweit 2002; Stotsky 1996, p. 14), and studies of gendered spending patterns over the past 20 years have consistently shown that household finances should not be regarded as pooled funds (see, for example, Sonnenberg et al. 2011). A gender impact analysis of intra-household finances will examine not only who earns the money, but how financial resources are managed and controlled. Although researchers report that women are taking a more active role in household financial decisions, there is some evidence that this control is nominal rather than in substance, meaning that management does not equate to control (Bennett et al. 2010).

Gender bias in consumption taxes is most likely to result from different consumption patterns between men and women. Applying a human rights approach, a larger proportion of spending by women is on household necessities (Bennett et al. 2010). Gendered spending patterns within households result in a transfer of taxes and benefits from 'purse to wallet'. This has been explicitly recognised in relation to the delivery of benefits based on children and family, which are more effectively delivered directly to the primary carer than through tax concessions to the breadwinner in the family, as they are more likely to be applied for the benefit of those children (ANOP Market Research 1985; Goode et al. 1998), and is also recognised in Article 9 of ICESCR and Article 13 of CEDAW, which explicitly recognise the rights for everyone to receive social security.

Elson (2006, p. 88) goes further in applying the human rights framework, to note that spending patterns vary between higher and lower income families, and that tax policymakers should also take into account inequality between women, to ensure that assistance can be redistributed to women and families facing multiple disadvantages. Low-income households are more likely to be headed by women, and in both developed and emerging economies, single-parent households are over-represented among the lowest income households in the economy. The GST is acknowledged as a regressive tax; therefore, the burden will fall more heavily on those households.

Certain categories of expenditures are more significant in a household budget, and this may be reflected in the structure of the broad-based consumption tax adopted in a particular jurisdiction. The OECD (2014) notes that most OECD countries have reduced rates for a range of goods and services. There are four main categories of reduced rates: 
- basic essentials (food, medical, energy and water)

- utilities that may have been publicly provided (public transport, postal services and telecommunications)

- activities that provide social benefits (charitable activities, culture, support or employment services)

- geographic locations that are considered to warrant special treatment.

Certain categories of spending merit special consideration under the relevant treaties, which protect the right to adequate food, clothing and housing for an individual and their family (ICESCR Article 11); education (CEDAW Article 10); and health care (ICESCR Article 12, CEDAW Article 12).

An example of an exemption with an implicit gender bias toward women is the zero rate applied to children's clothing and footwear in Ireland and the United Kingdom, which is not available on other clothing. As children's clothing is likely to be purchased by the primary carer, the lower VAT rate will reduce the cost to that parent, which will flow through to the family budget. In contrast, a broad-based consumption tax without exemptions, as in New Zealand, is likely to have a gender bias against women as women are responsible for more of the spending within the household. The OECD goes on to say:

The OECD study confirms and provides evidence that most, if not all, of the reduced rates that are introduced to support the poor, such as reduced rates on food and on energy products, do have the desired progressive effect. Nevertheless, it clearly shows that despite this progressive effect, reduced VAT rates are a poor tool for targeting support to poor households. Alternative compensation methods usually proposed are direct compensation through transfer payments or reductions in other personal taxes, notably restructured income tax rate schedules. The report goes on to note that where alternative methods of delivery of benefits are not available, reduced rates may be the most appropriate tool. Thus, each system needs to be considered on a case by case basis (OECD 2014, p. 57).

Given that any increase in consumption taxes has an implicit adverse impact on women, any compensation should also be delivered symmetrically, to recompense women. Income tax cuts would result in a transfer from purse to wallet due to the lower workforce participation rate and lower income earned by women in both developed and emerging economies. However, compensation delivered through the transfer system is subject 
to politics, and is at risk of being scaled back if fiscal policy deteriorates, as was evident across the OECD following the Global Financial Crisis (GFC) (UN Women 2015, p. 195).

Australia has a single-rate GST with a range of exemptions including food, health, education and financial services. Reform proposals in relation to the GST are based around either increasing the rate and/or the base of the GST. Australia has comparatively strong public funding of both health and education. The Treasury has argued (2015, p. 136) that the GST exemptions on these items are regressive as private health and education services are accessed by higher income Australians. Phillips and Taylor (2015), in modelling for the National Centre for Social and Economic Modelling (NATSEM), support this in respect of education, finding that expanding the GST base to include private education would be neither progressive nor regressive, but in respect of food, health and water an expansion in the base would be regressive. The modelling included a breakdown between male- and female-headed households. The differences were most notable in respect of health and education, with more maleheaded households adversely affected by the inclusion of health (79.9 per cent to 74 per cent) and education (32.7 per cent to 24.5 per cent). This could be a consequence of the over-representation of female-headed households in lower-income quintiles, with lower use of private health and education services.

The results of modelling an increase in the rate of the GST to 13 per cent or 15 per cent show that all quintiles would be worse off (Phillips and Taylor 2015, Tables 17 and 18), which would require compensation to be paid to low-income earners following any change in the base or rate of the GST. Phillips and Taylor went on to examine the outcome if changes to the GST were combined with lower PIT rates. Increases of 3 and 5 per cent in the tax rate were shown to be regressive overall, with femaleheaded households significantly worse off (2015, p. 57). This supports the proposition that compensation is better targeted through the transfer system.

Spending patterns also vary between higher- and lower-income families. As such, tax policymakers should also take into account inequality between women, to ensure that assistance can be redistributed to women and families facing multiple disadvantages. 


\section{Property taxes}

One of the UN Women empowerment goals is to increase the level of land and other asset holdings by women, as this will provide a more secure economic base to build capabilities, and will provide more secure housing (UN Women 2015). There may be assumptions made about the ownership of property that are reflected in taxation systems; for example if property is assumed to be held by a male partner this may give rise to gender bias in a taxation system (Stotsky 1997). Housing is of particular concern to women who are likely to hold a higher proportion of their wealth in their primary residence (Austen et al. 2014; Cobb-Clark and Hildebrand 2011). Consequently, tax concessions relating to the principal residence are likely to favour women, and proposals to wind back such concessions will have an adverse gender impact.

A gender analysis of property taxes depends on the structure of the particular tax. A progressive wealth tax that is redistributive will increase the revenue available to provide services that benefit women and other economically disadvantaged groups. However, property and land taxes are often levied at a decentralised level and are related to the provision of local services. If these taxes are levied without reference to the taxpayer's ability to pay they are a form of user fee (Barnett and Grown 2004, p. 19), which UN Women identifies as one of the most regressive forms of financing the provision of services (UN Women 2015, p. 207).

The gender impact of property taxes will vary significantly between developed and emerging countries. In emerging countries, the challenge is to address legal barriers to women holding property and cultural norms that favour the transfer of family assets to males. For example, in India prior to 1956, the inheritance system under Hindu law created gender inequity in property ownership, which was reflected in the taxation system. This was addressed by the Hindu Succession Act 1956, which allowed a Hindu woman to inherit property. In developed economies, where the legal barriers have been removed, a human rights fiscal policy framework should focus less on the legal ownership of property and more on control over the property in question.

The ability to minimise tax through property transfers between spouses has a regressive impact that reduces the ability of the state to fund other necessary services. Income splitting strategies often depend on a change in ownership of assets as an element in tax planning strategies (Baron 2013; 
Edwards 1986; Cullen and Dunne 2008; Hodgson 2008), so that the transfer of property between spouses erodes the tax base. Such transfers may be nominal only, with control of the asset remaining with the original owner of the asset, which may or may not result in improved bargaining power and economic empowerment (this is also discussed in Chapter 9 with regard to high-income women). Management of income and assets may be separated from control of that income or asset within a household, so that the person who manages the day-to-day operational decisions over income and spending may not be the person who controls the household income. This can be extrapolated to the management of financial assets: although legal ownership of the assets may be transferred, economic control of the asset may remain with the original owner, and property taxes are an appropriate way to maintain the progressivity of the taxation system.

Property rights are integral to economic rights, and UN Women recognises that women are disadvantaged where they do not have access to property. However, ownership of property may be separated from effective control, and property transfers may be a means of eroding fiscal adequacy through tax planning or income splitting strategies. These tax planning practices increase inequality between women as it reduces the fiscal resources the government needs to deliver social services. The application of transactional taxes on transfers and progressive wealth-based taxes on such assets is a tool that can be applied to address such tax planning practices.

\section{Retirement income schemes (superannuation)}

Retirement income insurance schemes, such as the superannuation system in Australia, which require contributions from wage income towards retirement saving, are classified by UN Women as among the more regressive social levies (UN Women 2015, p. 207). Although retirement income schemes are not taxes, to the extent that they are compulsory levies the principles of gender impact analysis should be applied, as explained in Sharp et al. (2015). These schemes are specifically recognised in human rights treaties as follows:

ICESCR Article 9: ... recognise the right of everyone to social security, including social insurance ... (ICESCR 1966, Article 9)

CEDAW Article 11: ... Ensure that women have access to the same benefits, compensatory schemes and allowances as men, especially in relation to retirement and incapacity to work ... (CEDAW 1979, Article 11) 
In particular, women should have access to an income stream in retirement that is independent of other family members. If pensions are paid to the male head of the household, women are economically dependant on that person as they do not have control over their own finances. In systems where pensions are paid separately to each eligible member of the household, to the extent that pension levels are determined on family or household income, this principle may still be contravened as members of the household may not share income and assets. Retirement savings systems should be designed to encourage independent income streams following retirement.

The World Bank framework to provide a secure retirement income consists of a multi-tiered approach to funding retirement income (Holzmann et al. 2008). The zero-level tier consists of a universal state-funded pension entitlement; mandated contributory retirement income schemes make up the first and second tiers; and the third tier is made up of voluntary selfprovision. The final, fourth tier consists of non-financial services including health provision and housing.

The basic or social pension is often the main source of income in retirement for women who have not participated in the paid economy (UN Women 2015, p. 155), and as such it is essential that social pension schemes be maintained at a level that ensures that the recipient can meet the basic living requirements. However, due to the fiscal cost of providing such pensions, governments will usually restrict eligibility through means tests or other limitations. Accordingly, social pensions are frequently provided as safety net measures rather than a universal entitlement. An adequate level of retirement income will generally require a combination of a universal base level pension and contributory pensions (UN Women 2015, p. 156). Contributory pensions or mandatory savings schemes provide further insurance against poverty in old age.

From a gender perspective, however, contributory schemes perpetuate the gender gaps that emerge earlier in life. Contributory schemes operate as a form of insurance by requiring that contributions are made on the basis of income earned while the contributor is working: they effectively spread the income earned while working across the contributor's life span. Women are at a disadvantage in systems of this type, as they are generally most effective where a contributor has a stable source of income over a lengthy working life. They do not generally address the typical female pattern of reduced participation in the paid labour market during child-rearing years 
(Hodgson and Marriott 2013). This is exacerbated by the earlier retirement age provided under many schemes and the longer life expectancy. In this context, UN Women recommend that access to contributory schemes be equalised, and that female paid workforce patterns be considered in the design of such schemes. They also recommend that carer credits be made available to women who are not participating in the paid labour market due to care responsibilities (UN Women 2015, p. 155).

The third tier of the World Bank model includes self-provision schemes that encourage private savings to fund retirement. Such schemes are even more regressive than first- and second-tier schemes, as they are dependant on the participant having sufficient funds to save for retirement. For reasons discussed above, women are less likely than men to have funds available to invest in third-tier schemes. Phipps and Woolley (2008) examined the allocation of retirement savings within Canadian households. They found that even where women take control of the family finances, retirement savings are more likely to be held by men. This has important consequences for bargaining within older households: given the longer lives and earlier retirement ages of women, their retirement savings must be consumed at a slower rate than by their partner. This can lead to conflict over resource allocation where one party controls retirement savings.

The fourth tier of the retirement income system is important in developing a human rights approach to fiscal policy. Under the relevant treaties, participants are required to protect the right to adequate housing (ICESCR Article 11) and health care (ICESCR Article 12; CEDAW Article 12). Social housing and public health care should be available to ensure that the human rights of all persons, including pensioners, are protected. Fiscal policy must ensure the collection of adequate levels of revenue to fund these systems.

As discussed by Austen and Sharp in Chapter 10, in Australia the difference in workforce participation between men and women has generated a gender gap in superannuation contributions (Senate Economics Reference Committee 2016). This is exacerbated by tax on retirement savings, which is particularly regressive as tax concessions are available to both second- and third-tier retirement savings. Not only do higher-income earners contribute more through the mandated level of superannuation guarantee contributions based on payroll, they also have the ability to make higher levels of voluntary contributions. 
The gender impact of the tax concession is twofold: women benefit less from the concessions that are available and the tax concessions on retirement savings redirect public money to retirement savings holders, generally men, away from pension recipients, who are more likely women. This imbalance can only be addressed by scaling back the extent of the tax concessions available on retirement savings, and redirecting the savings to social benefit programs.

The ICESCR specifically recognises that states should protect the right to an adequate standard of living, including food, clothing, housing (Article 11) and health (Article 12). The CEDAW adds the protection of equal access to education and training (Article 10). These treaties also require states recognise the right of everyone to social security, including social insurance (ICESCR Article 9), and that they have access to the same retirement and incapacity benefits as men (CEDAW Article 11). Consequently, policy considerations around retirement savings taxes need to take into account implicit bias. Retirement income schemes need to be redesigned to account for the different work and care responsibilities that women face, which impact on the ability of women to contribute consistently to contributory schemes.

\section{Conclusion}

Following the GFC, developed economies implemented austerity regimes in the tax-transfer systems that have had a significant impact on the economic security of women. Aggressive tax reform proposals, coupled with austerity measures, mean that women are further from substantive economic and social gender equality than they were 30 years ago (Nelson 2015). This result is arguably due to the neoliberal approach to macroeconomic policy adopted by nations where the focus is on taxing for growth rather than a broader objective of taxing for social policy, which includes growth as part of the consideration. Such an approach is detrimental to gender equality. As Professor Kathleen Lahey explains, 'the negative effects of [just] taxing for growth on the status of women, poverty levels, and human development has been pervasive and profound' (Lahey 2015, p. 9; and see Chapter 2, this volume).

In the dominant fiscal policy approach, there is a traditional emphasis on the criteria of equity, efficiency and ease of administration as the primary relevant design criteria for tax reform (Elson 2006, p. 72). As we discuss 
in this chapter, the concepts of equity and efficiency have been critically assessed in the tax and feminist literature, in particular highlighting their limitations in analysing and addressing explicit and implicit gender inequality (see, for example, Hui 2013). Gender-responsive budgeting, including both gender impact analysis and political engagement components, has made significant inroads in some countries. However, much of this work focuses on an analysis of existing tax regimes, specific taxes and specific policies, rather than developing a holistic approach to tax system design that provides a macro-economic framework that takes into account gender inequality.

This chapter has argued that we should go beyond such analysis in proposing the application of a human rights framework to fiscal policy. It is recognised that human rights principles and the ensuing legislative enactment of the required standards only provide the basis for equality. As UN Women explains:

Power inequalities, structural constraints and discriminatory social norms and practices also need to be addressed ... Formal equality may result in unequal outcomes, and policies may need to treat women differently to men treatment to achieve equality ... Despite the implementation of these human rights treaties, women continue to experience economic inequality. States, therefore, must adopt a proactive role as arbiters of social and economic rights (UN Women 2015, pp. 24-25).

While human rights principles and treaties may provide a basis for equality, the formal recognition and application of a human rights framework may go far in ensuring gender inequality is considered throughout the fiscal process, and not just as an ex-post analysis tool. This chapter explicitly applied the human rights treaties and the UN Women human rights framework for fiscal policy strategies to four areas of tax policy in Australia: PIT, GST, property taxes and taxes on retirement savings. In each case study, we demonstrated that a human rights-based framework would result in different considerations and different outcomes for gender equality.

\section{References}

Adam, Stuart and Mike Brewer. 2012. Couple Penalties and Premiums in the UK Tax and Benefit System. UK: Institute for Fiscal Studies. 
ANOP Market Research. 1985. What Women Think: A Survey of Mothers' Attitudes to Family Allowance, The Dependent Spouse Rebate and Family Finances. Prepared for the Office of the Status of Women Department of the Prime Minister and Cabinet. Canberra: Australian Government Publishing Service.

Apps, Patricia. 2010. 'Why the Henry Review Fails on Family Tax Reform'. In Chris Evans, Richard Krever and Peter Mellor (eds), Australia's Future Tax System: The Prospects After Henry. Essays in Honour of John W Freebairn, pp. 103-127. Sydney: Thomson Reuters.

ATO (Australian Tax Office). 2012. Tax Statistics 2012-13. Table 9. Available at: data.gov.au/dataset/taxation-statistics-2012-13

Austen, Siobhan, Therese Jefferson and Rachel Ong. 2014. 'The Gender Gap in Financial Security: What We Know and Don't Know about Australian Households'. Feminist Economics 20(3): 25-52. doi. org/10.1080/13545701.2014.911413

Baird, Marian, Michele Ford and Elizabeth Hill (eds). 2017. Women, Work and Care in the Asia Pacific. ASAA Women in Asia series. Routledge.

Barnett, Kathleen and Caren Grown. 2004. Gender Impacts of Government Revenue Collection: The Case of Taxation. London: Commonwealth Secretariat. doi.org/10.14217/9781848590205-en

Baron, Gabriel. 2013. 'Selected Considerations in the Use of Professional Corporations'. Canadian Tax Journal 61(4): 1167-1192.

Baxter, Janeen, Belinda Hewitt and Michele Haynes. 2008. 'Life Course Transitions and Housework: Marriage, Parenthood, and Time on Housework'. Journal of Marriage and Family 70(2): 259-272. doi. org/10.1111/j.1741-3737.2008.00479.x

Bennett Fran, Jerome De Hanau and Sirin Sung. 2010. 'Withinhousehold inequalities across classes? Management and control of money'. In Jacqueline Scott, Rosemary Crompton and Clare Lyonette (eds), Gender Inequalities in the 21st Century, pp. 215-241. Edward Elgar.

Cobb-Clark, Deborah A. and Vincent A. Hildebrand. 2011. 'Portfolio Allocation in the Face of a Means-Tested Public Pension'. Review of Income \& Wealth 57(3): 536-560. doi.org/10.1111/j.14754991.2011.00437.x 
Craig, Lyn. 2007. 'How Employed Mothers in Australia Find Time for Both Market Work and Childcare'. Journal of Family and Economic Issues 28(1): 69-87. doi.org/10.1007/s10834-006-9047-2

Cullen, Michael and Peter Dunne. 2008. Income Splitting for Families with Children: A government tax policy discussion document. Wellington: Policy Advice Division of Inland Revenue.

Dolamore, Robert. 2015. The tools of macroeconomic policy-a short primer. Parliament of Australia. Available at: www.aph.gov.au/About Parliament/Parliamentary_Departments/Parliamentary_Library/pubs/ BriefingBook44p/MacroeconomicPolicy

Donald, Kate. 2015. Women's Rights and Revenues: Why We Can't Achieve Gender Equality Without Fiscal Justice. 26 March, Centre for Economic and Social Rights, New York.

Edwards, Meredith. 1986. 'The Australian Tax Unit: An Evaluation'. In John G. Head (ed.), Changing the Tax Mix: Papers Presented at a Conference Organised by the Centre of Policy Studies, Monash University. Australian Tax Research Foundation Conference Series No. 6. Sydney: Australian Tax Research Foundation.

Elson, Diane. 2006. Budgeting for Women's Rights: Monitoring Government Budgets for Compliance with CEDAW. New York: United Nations Development Fund for Women. Available at: internationalbudget.org/ wp-content/uploads/Budgeting-for-Women $\%$ E2\%80\%99s-RightsMonitoring-Government-Budgets-for-Compliance-with-CEDAW. pdf

Elson, Diane. 2015. 'Gender Equality Requires More Tax Revenue'. Tax Justice Focus 10(1): 8.

Goode, Jackie, Claire Callender and Ruth Lister. 1998. Purse or Wallet? Gender Inequalities and Income Distribution within Families on Benefits, Findings. Joseph Rowntree Foundation.

Grown, Caren and Imraan Valodia. 2010. Taxation and Gender Equity: A Comparative Analysis of Direct and Indirect Taxes. Taylor and Francis.

Harding, Michelle. 2013. 'Taxation of Dividend, Interest and Capital Gain Income'. OECD Taxation Working Papers. OECD. dx.doi. org/10.1787/222 
Himmelweit, Susan. 2002. 'Making Visible the Hidden Economy: The Case for Gender Impact Analysis of Economic Policy'. Feminist Economics 8(1): 49-70. doi.org/10.1080/13545700110104864

Hodgson, Helen. 2008. 'Taxing the Family-The Tax Unit: Should NZ Adopt a Family Based Income Tax?' New Zealand Journal of Taxation Law and Policy 14(3): 398-412.

Hodgson, Helen and Lisa Marriott. 2013. 'Retirement Savings and Gender: An Australasian Comparison'. Australian Tax Forum 28(4): $725-752$.

Holzmann, Robert; Richard Paul Hinz and Mark Dorfman. 2008. Pension Systems and Reform Conceptual Framework. SP Discussion Paper No. 0824. World Bank. Available at: documents.worldbank.org/curated/ en/716871468156888545/pdf/461750NWP0Box334081B01 PUBLIC10SP00824.pdf

HRC (Human Rights Commission of Australia). 2015. Woman of the World: What is CEDAW. Available at: www.humanrights.gov.au/ publications/woman-world-what-cedaw

Hui, Neha. 2013. Gender Implications of Budget Policies. New Delhi: Centre for Budget and Governance Accountability.

IMF (International Monetary Fund). 2014. Fiscal Policy and Income Equality. IMF Policy Paper. Washington DC: International Monetary Fund. Available at: www.imf.org/external/np/pp/eng/2014/012314. pdf

Lahey, Kathleen. 2015. 'Women and Taxation-From Taxing for Growth and Tax Competition to Taxing for Sex Equality'. Tax Justice Focus 10(1): 8-10.

Nelson, Liz. 2015. 'Gender and Tax Justice'. Tax Justice Focus 10(1): 4-5.

OECD (Organisation for Economic Co-operation and Development). 2007. Encouraging Savings through Tax-Preferred Accounts. OECD Tax Policy Studies No. 15. Paris: OECD Publishing.

OECD. 2014. Consumption Tax Trends 2014: VAT/GST and excise rates, trends and policy issues. Paris: OECD Publishing. 
Phillips, Ben and Matt Taylor. 2015. The Distributional Impact of the GST. Canberra: National Centre for Social and Economic Modelling. Available at: www.natsem.canberra.edu.au/storage/ACOSS\%20GST \%20Report.pdf

Phipps, Shelley and Frances Woolley. 2008. 'Control over money and the savings decisions of Canadian households'. The Journal of SocioEconomics: Special Issue on the Household Economy 37(2): 592-611. doi.org/10.1016/j.socec.2006.12.042

Senate Economics Reference Committee. 2016. Report of the Inquiry into Economic Security for Women in Retirement: A Husband is Not a Retirement Plan. Australian Senate. Available at: www.aph.gov.au/ Parliamentary_Business/Committees/Senate/Economics/Economic_ security_for_women_in_retirement/Report

Sharp, Rhonda, Siobhan Austen and Helen Hodgson. 2015. 'Gender Impact Analysis and the Taxation of Retirement Income Savings in Australia'. Australian Tax Forum 60: 763-781.

Sonnenberg, Stefanie J, Carole B Burgoyne and David A Routh. 2011. 'Income Disparity and Norms Relating to Intra-Household Financial Organisation in the UK: A Dimensional Analysis'. The Journal of Socioeconomics 40(5): 573-582. doi.org/10.1016/j.socec.2011.04.014

Stewart, Miranda. 2011. 'Gender Equity in Australia's Tax System: A Capabilities Approach'. In Kim Brooks, Asa Gunnarson, Lisa Philipps and Maria Wersig (eds), Challenging Gender Inequality in Tax Policy Making, pp. 53-74. Hart Publishing.

Stotsky, Janet. 1996. Gender Bias in Tax Systems. IMF Working Paper No. 96/99. International Monetary Fund. Available at: www.imf. org/en/Publications/WP/Issues/2016/12/30/Gender-Bias-in-TaxSystems-2074

Stotsky, Janet. 1997. 'How Tax Systems treat Men and Women Differently'. Finance and Development March, pp. 30-33. Available at: www.imf. org/external/pubs/ft/fandd/1997/03/pdf/stotsky.pdf

Treasury. 2015. Re:Think Tax Discussion Paper. Australian Government. Available at: bettertax.gov.au/files/2015/03/TWP_combined-online.pdf 
UN (United Nations) Women. 2015. Progress of the World's Women 2015-16. Available at: progress.unwomen.org/en/2015/

World Bank. 2015. World Development Indicators. Available at: data. worldbank.org/data-catalog/world-development-indicators

Young, Claire. 1999. 'Taxing Times for Women: Feminism Confronts Tax Policy'. Sydney Law Review 21(3): 487-499.

\section{Treaties and other materials}

Convention on the Elimination of All Forms of Discrimination Against Women (CEDAW). 1979. Available at: www.humanrights.gov.au/ convention-elimination-all-forms-discrimination-against-womenhuman-rights-your-fingertips-human

International Covenant on Economic, Social and Cultural Rights (ICESCR). 1966. Available at: www.humanrights.gov.au/internationalcovenant-economic-social-and-cultural-rights-human-rights-yourfingertips-human-rights 
This text is taken from Tax, Social Policy and Gender: Rethinking equality and efficiency, edited by Miranda Stewart, published 2017 by ANU Press, The Australian National University, Canberra, Australia.

dx.doi.org/10.22459/TSPG.11.2017.04 